\title{
Microfluidization of model dairy emulsions. II. Influence of composition and process factors on the protein surface concentration
}

\author{
O Robin ${ }^{1 *}$, M Kalab $^{2}$, M Britten 3 , P Paquin ${ }^{1}$ \\ ${ }^{1}$ Centre de recherche en sciences et technologies du lait (STELA), Département de sciences \\ et technologies des aliments, université Laval, Québec, PQ, G1K $7 P 4 ;{ }^{2}$ Centre for Food \\ and Animal Research, Agriculture and Agri-Food Canada, Ottawa, K1A OC6, ON; \\ ${ }^{3}$ Centre de recherche des aliments (CRDA), Agriculture Canada, 3600, Blvd Casavant Ouest, \\ Saint-Hyacinthe, J2S 8E3, PQ, Canada
}

(Received 12 February 1996; accepted 25 July 1996)

\begin{abstract}
Summary - The influence of some composition variables (butter oil, sodium caseinate and monoglyceride contents) and process variables (pressure and temperature) on the relative adsorbed protein fraction $\left(F_{a d s}, \%\right)$ and on the protein load $\left(\Gamma, \mathrm{mg} \mathrm{m}^{-2}\right)$ of fat globules was studied in a model dairy emulsion (oil-in-water produced by microfluidization). The amount of adsorbed proteins $\left(F_{a d s}\right.$ and $\Gamma$ ) was evaluated immediately after emulsification by coupling the separation of oil and aqueous phases of the emulsion produced by centrifugation to the determination of protein content. The specific surface area $\left(A_{s p}\right)$ of oil-water interface was obtained by photon correlation spectroscopy after the protein aggregates were dissociated by an appropriate buffer. A central composite experimental design was used to obtain two nonlinear multiple regression equations relating $F_{\text {ads }}$ and $\Gamma$ to sodium caseinate ( 0.5 to $3.9 \mathrm{wt} \%$ ), butter oil (5.2 to $14.7 \mathrm{wt} \%$ ) and monoglyceride (0.08 to $0.88 \mathrm{wt} \%$ ) contents, and to the emulsification pressure $(7.8$ to $76.3 \mathrm{MPa})$ and temperature $\left(35\right.$ to $\left.100^{\circ} \mathrm{C}\right)$. These two functions explained 92.7 and $90.6 \%$ of the variation in $F_{\text {ads }}$ and in $\Gamma$, respectively, and made it possible to evaluate the independent influence of each experimental variable. The results indicate that the sodium caseinates (NaCas), as a group, seem much less easily adsorbed than monoglyceride (glycerol monostearate, GMS) molecules when the GMS:NaCas molecular ratio $(R)$ is higher than 5 : more numerous and possibly more surface active than proteins, monoglycerides probably settle at the interface quicker than proteins. A qualitative model is also presented to illustrate this possible competition and estimate its influence on the parameters that characterize protein adsorption ( $F_{a d s}$ and $\Gamma$ ) and fat globule size ( $d_{v s}$ ).
\end{abstract}

protein surface adsorption / protein load / protein-surfactant competition / microfluidization / milkfat globule / oil-in-water emulsion / emulsification

Résumé - Microfluidisation d'émulsions laitières modèles. II. Influence des facteurs de procédés et de formulation sur la concentration de protéines à l'interface. L'influence de certaines variables de composition (teneurs en huile de beurre, caséinates de sodium, et monoglycérides) et

\footnotetext{
* Correspondence and reprints: NESTEC Ltd, Research Centre, Vers-Chez-Les-Blanc, PO Box 44, C-1000 Lausanne 26, Switzerland.
} 
de procédé (pression et température) sur la fraction de protéines adsorbées à l'interface $\left(F_{\text {ads, }} \%\right.$ ) et sur la charge protéique $\left(\Gamma, \mathrm{mg} \mathrm{m}^{2}\right)$ des globules gras d'une émulsion produite par microfluidisation a été étudiée. L'évaluation de la quantité de protéines adsorbées ( $F_{a d s}$ et $\Gamma$ ) a été réalisée juste après l'émulsification en associant la séparation des phases aqueuse et lipidique de l'émulsion par centrifugation à une détermination de la teneur en protéines. La surface spécifique $\left(A_{s p}\right)$ des globules gras a été évaluée par spectroscopie de corrélation photonique après que les agrégats protéiques aient été dissociés dans un tampon approprié. L'utilisation d'un dispositif expérimental de type central composite a permis d'obtenir deux équations de régression multiple non linéaires reliant $F_{\text {ads }}(\%)$ et $\Gamma\left(m g m^{-2}\right)$ aux teneurs en caséinates de sodium (0,5 à 3,9\%), huile de beurre $(5,2$ à $14,7 \%)$ et monoglycérides $(0,08$ à $0,88 \%)$, à la pression $(7,8$ à $76,3 \mathrm{MPa})$ et à la température d'émulsification $\left(35\right.$ à $100{ }^{\circ} \mathrm{C}$ ). Ces deux fonctions expliquent respectivement $92,7 \%$ et $90,6 \%$ des variations de la fraction protéique adsorbée et de la charge protéique des globules gras dans l'intervalle de valeurs des paramètres considérés. Les résultats indiquent que les caséinates de sodium (NaCas), en tant que groupe, semblent moins facilement adsorbés que les monoglycérides lorsque le ratio moléculaire GMS:NaCas (R) est supérieur à 5: plus nombreux et peut-être plus tensioactifs que les protéines, les monoglycérides colonisent probablement l'interface plus rapidement que les protéines. Un modèle qualitatif représentant cette possible compétition et son influence sur les paramètres caractérisant l'adsorption protéique ( $F_{\text {ads }}$ et $\Gamma$ ) et la taille des globules gras $\left(d_{v s}\right)$ est également proposé.

\section{adsorption protéique en surface / charge protéique / compétition protéine-surfactant / microfluidisation / globule gras / émulsion huile-dans-l'eau / émulsification}

\section{ABBREVIATIONS}

$A_{s p}$ : specific surface of fat globules $\left(\mathrm{m}^{2} \mathrm{~kg}^{-1}\right)$;

$A_{i}$ : total surface area of fat globules $\left(\mathrm{m}^{2}\right)$;

[BO]: butter oil concentration (wt \%);

$\mathrm{CV}$ : coefficient of variation of the volume-weighted size distribution (\%);

$d_{v s}$ : volume-weighted average fat globule diameter $(\mathrm{m})$;

$F$ : number of factorial points of the design or Fisher ratio (dimensionless);

$F_{\text {ads: }}$ adsorbed protein fraction (\%);

g: gravitational constant $\left(9.81 \mathrm{~m} \mathrm{~s}^{-2}\right)$;

[GMS]: monoglyceride concentration (wt\%);

$k$ : number of independent variables (dimensionless);

$M_{1}$ : total mass of fat globules (dimensionless);

[Prot]: protein concentration (wt\%);

$P$ : emulsification pressure $\left(\mathrm{Pa}=\mathrm{m}^{-1} \mathrm{~kg} \mathrm{~s}^{-2}\right)$;

$r$. rotor radius $(m)$;

$R:$ GMS:protein molecular ratio (dimensionless);

$T$ : emulsification temperature $(\mathrm{K})$;

$x$ : independent variable;

$x_{B O}$ : mass fraction of butter oil (dimensionless);

$x_{G M S}:$ mass fraction of monoglycerides (dimensionless);

$y$ : dependent variable;

$\beta$ : coefficients determined by the least squares method (dimension variable);

$\varepsilon:$ random component error (dimension variable);

$\phi:$ volume fraction of the dispersed phase (dimensionless);

$\phi_{\text {cas }}:$ volume fraction of the casein micelles in milk (dimensionless);

$\gamma$ : interfacial tension $\left(\mathrm{N} \mathrm{m}^{-1}=\mathrm{kg} \mathrm{s}^{-2}\right)$;

Г: protein load $\left(\mathrm{g} \mathrm{m}^{-2}\right)$;

$\rho$ : mass density $\left(\mathrm{kg} \mathrm{m}^{-3}\right)$;

$\rho_{\text {Milk }^{2}}{ }^{\circ} \mathrm{C}$ : mass density of milk $\left(\mathrm{kg} \mathrm{m}^{-3}\right)$;

$\rho_{B O}$ : mass density of butter oil $\left(\mathrm{kg} \mathrm{m}^{-3}\right)$;

$\rho_{M G S}$ : mass density of monoglycerides $\left(\mathrm{kg} \mathrm{m}^{-3}\right)$;

$\sigma_{\text {Fads }}:$ variance of the adsorbed protein fraction (dimensionless);

$\sigma_{\Gamma}$ : variance of the protein load $\left(\mathrm{g}^{2} \mathrm{~m}^{-4}\right)$. 


\section{INTRODUCTION}

In food emulsions, there are mainly two classes of molecules that show a strong tendency to accumulate at the dispersed droplet surface during emulsification. These molecules are proteins and low molecular mass surfactants, respectively (Dickinson et al, 1990). Although these two classes of molecules influence emulsion behavior (eg, emulsion formation, kinetic stability, flow properties, etc), the magnitude of their effects is different. Indeed, due to their differences in composition and conformation, their influence based on physical interactions for both of them, whether intermolecular or intramolecular, and mediated by the chemical nature of the environment on either side of the interface, is different (Fisher and Parker, 1988). By lowering the interfacial tension between the phases, emulsifiers generally reduce the Laplace pressure and pressure gradients required to disperse one phase into the other (Walstra, 1983). Small molecule surfactants, however, lead to the formation of smaller droplets, by lowering the interfacial tension much more strongly than proteins alone. This is associated with a higher Gibbs elasticity of the film between pairs of approaching droplets during emulsification (Dickinson et al, 1989b). Similarly, by accumulating at interfaces, emulsifiers surround fat globules and form a stabilizing layer on their surfaces which protects them against subsequent coalescence. The structure and properties of that layer, which remarkably influence the properties of emulsions (eg, stability and rheology), is widely determined by the nature of the emulsifiers used. On the one hand, protein layers appear rather viscoelastic and tend to dampen down surface fluctuations and to inhibit the mechanism responsible for film rupture; on the other hand, small molecule surfactants which induce low interfacial tension gradients and low shear surface viscosities seem less efficient at preventing layer rup- ture (Walstra, 1987; Dickinson, 1992). As a first approximation, stability with respect to coalescence tends to increase with the increase of surface viscosity. The relationship between surface viscosity and stability is not clear, however. Random coil-type proteins (eg, caseins) form layers with little cohesiveness (low viscosity) compared to globular proteins (eg, whey proteins) which retain a major portion of their tertiary structure and form layers of higher viscosity (Boyd et al, 1973; Graham and Phillips, 1980; Castle et al, 1987). Nevertheless, it is well known that the former protein type produces more stable emulsions than the latter (Leman and Kinsella, 1989; Lorient et al, 1991). Furthermore, small molecule surfactants, at concentrations well above monolayer coverage, may also provide some additional stabilization by forming liquid crystals at the interface (Friberg et al, 1976; Krog, 1990) or in the continuous phase between oil droplets (Barry, 1975).

All these trends, generally observed in model systems containing either one source of emulsifier (protein or low molecular mass surfactants) or a mixture of two pure surfactants, are further complicated in real systems, such as dairy emulsions. In the latter systems, milk proteins (casein and whey proteins) and oil-soluble low molecular mass surfactants (monoglycerides, phospholipids, free fatty acids, etc) are invariably present in mixture. Two other classes of phenomena must be added to this new situation. First, the difference in magnitude of their own effects leads to competition for space at the interface between i) the various milk protein components (Dickinson et al, 1989a, 1993; Britten and Giroux, 1991; Dalgleish et al, 1991; Dickinson and Gelin, 1992); ii) the various low molecular mass surfactants, deliberately added or inevitably present in oil fraction (Gaonkar and Borwankar, 1991); and finally iii) between these surfactants and the proteins (Dickinson et al, 1990; Courthaudon et al, 1991a, b, c; Dickinson and Tanai, 
1992a; Tomas et al, 1994b). In the latter case, strong and thickly adsorbed layers produced by interactions between proteins and surfactants have also been reported (Wüstneck et al, 1984; Doxastakis and Sherman, 1986; Wüstneck and Müller, 1986). Second, milk proteins can also be partially or totally displaced from the interface by low molecular surfactants, as has been theoretically predicted (Cohen Stuart et al, 1984) and experimentally observed (Oortwijn and Walstra, 1979; De Feijter et al, 1987; Dickinson et al, 1989c; Heertje et al, 1990; Courthaudon et al, 1991b, c; Krog, 1991). In practice, however, a clear distinction between competitive adsorption and displacement is sometimes difficult. Indeed, the ease as well as the extent of protein displacement by other surface active molecules are narrowly linked to various factors such as the molecular mass (Walstra and Oortwijn, 1982; Brynda et al, 1986; Zsom, 1986), the hydrophobicity of proteins ( $\mathrm{Na}$ kai, 1983), the structure stability of proteins (Arai and Norde, 1990), the order of exposure to the interface (Dickinson et al, $1989 \mathrm{a})$, the age of the adsorbed protein layer (Dickinson and Matsumura, 1991), the extent of any thermal treatment (Das and Kinsella, 1990; Dickinson and Tanai, $1992 b)$, the protein glycosylation (Closs et al, 1990) and more.

In part I of this series (Robin et al, 1992), we showed the influence of some composition (butter oil, protein and surfactant concentrations) and process variables (pressure and temperature) on the microfluidized fat globule size distribution. From these results, it can be concluded that some competitive adsorption between caseins and monoglycerides occurs. The study of the effects of the same composition and process factors on the surface concentration of adsorbed proteins of microfluidized milkfat globules was carried out with respect to the possible competitive adsorption between proteins and monoglycerides. The amount of adsorbed proteins on milkfat globules in freshly made emulsions was consequently evaluated.

\section{MATERIALS AND METHODS}

\section{Emulsion ingredients}

Butter oil ( $99.1 \%$ anhydrous) with a density $p_{B O}{ }^{2{ }^{\circ} \mathrm{C}}=0.920$ (Liang and Shi, personal communication) was purchased from Ault Foods Limited (Mitchell, ON, Canada) and was stored at $-18{ }^{\circ} \mathrm{C}$. Distilled monoglycerides (Excel T-95) were obtained from Atkemix (Brantford, $\mathrm{ON}, \mathrm{Ca}-$ nada). They had an estimated molecular mass, as determined by gas chromatography, of $360 \mathrm{Da}$, an hydrophile-lipophile balance of 4.5 and the following composition in mass: $94 \%$ monoglycerides, $4 \%$ diglycerides, $1 \%$ glycerol and $1 \%$ fatty acids. Sodium caseinates $(89.3 \%$ protein, $50 \mathrm{mg} \mathrm{Ca} / 100 \mathrm{~g}$ ) with an approximated average molecular mass of $20000 \mathrm{Da}$ (Cheftel et al, 1985) were purchased from ICN Nutritional Biochemicals (Mississauga, ON, Canada).

\section{Experimental design and emulsion preparation}

As previously reported (Robin et al, 1992), a central composite rotatable design made up of $k=$ five factors with five levels, and one repetition was developed. The five factors that were varied in the preparation of the emulsions are the following: two process factors - emulsification pressure $(P)$, and temperature $(T)$, and three formulation factors - protein concentration ([Prof]) butter oil content $([B O])$ and monoglyceride content ([GMS]). It was anticipated that the influence of composition and process variables $(x)$ on the protein surface concentration, expressed in terms of adsorbed protein fraction $\left(F_{a d s}\right)$ and protein load $(\Gamma)$, could be deduced from a second order polynomial model:

$$
y=\beta_{0}+\sum_{i=1}^{5} \beta_{i} x_{i}+\sum_{i i}^{5.5} \beta_{i i} x_{i}^{2}+\sum_{i j \neq i}^{5} \sum_{i j}^{5} \beta_{i j}+\varepsilon
$$

where $y$ is the dependent variable ( $F_{\text {ads }}$ or $\Gamma$ ), $\beta_{i,} \beta_{i i}$ and $\beta_{i j}$ are coefficients determined by the least squares method, and $\varepsilon$ is the random component error.

A total of 52 emulsions, each of $600 \mathrm{~g}$, were produced and analyzed. They were prepared by melting butter oil at $50^{\circ} \mathrm{C}$ and mixing it with sodium caseinate aqueous solutions freshly made in bidistilled water at room temperature. The mix- 
ture contained $5.2,8,10,12$ or $14.8 w t \%$ of butter oil and $0.5,0.9,1.5,2.5$ or 3.9 wt $\%$ sodium caseinate based on protein content. The mixtures were then heated to the emulsification temperature $\left(35,55,70,85\right.$ or $\left.100^{\circ} \mathrm{C}\right)$, and the monoglycerides $(0.08,0.2,0.4,0.6$ or $0.88 w t \%)$ were added. Following premixing at $2000 \mathrm{rpm}$ for 2 $\mathrm{min}$ at the emulsification temperature, the dispersions were emulsified by microfluidization (model 110, Microfluidics Corporation, Newton, MA, USA), in a two-pass process. The first pass was carried out at $7.8,20.7,41.4,62.1$ or 76.3 $\mathrm{MPa}$ and the second at 4.8 MPa. Further details on the experimental design as well as on the emulsification method may be found in Robin et al (1992).

\section{Evaluation of the relative adsorbed protein fraction and the protein load of the emulsified fat globules}

Methods for determining the protein load $(\Gamma)$, ie, the amount of protein adsorbed per unit area of interface, are generally based on an evaluation of the specific surface area $\left(A_{s p}\right)$ of dispersed droplets and the amount of adsorbed proteins. This second parameter can be obtained by determining the protein content in the creamed layer, the serum layer or in both (Mulder and Walstra, 1974; Ogden et al, 1976; Tornberg, 1978; Oortwijn and Walstra, 1979; Blanchot, 1992) after centrifugation of the native emulsion. Recently, Hunt and Dalgleish (1994) described a direct method whereby the amount of adsorbed protein in emulsions is quantified by SDSPAGE followed by photometric scanning of the stained protein bands.

\section{Evaluation of the specific surface area in emulsion}

In the absence of an ideal method to determine the dispersed droplet size distribution parameters of an emulsion, a previously reported procedure based on photon correlation spectroscopy after the protein aggregates were dissociated by an appropriate buffer (Urea, EDTA, $\beta$-mercaptoethanol, $\mathrm{pH}$ 7) was used to evaluate the volume-weighted average diameter $\left(d_{v s}\right)$ and the relative standard deviation around the average (cV) (Robin and Paquin, 1991; Robin et al, 1992).

From the $d_{v s}$ of the fat globule size distribution, the specific surface area $\left(A_{s p}\right)$ can be deduced. Assuming that fat globules are perfect spheres,
$A_{s p}$ can be obtained from the ratio of the total area $\left(A_{t}\right)$ divided by the mass of an array of fat globules $\left(M_{\mathrm{t}}\right)$, according to:

$$
A_{s p}=\frac{A_{t}}{M_{t}}=\frac{n \pi d_{v s^{2}}}{\rho n \frac{\pi d_{v s}{ }^{3}}{6}}=\frac{6}{\rho d_{v s}}
$$

where $n$ is the total number of fat globules. $A_{s p}$ is in $\mathrm{m}^{2} \mathrm{~g}^{-1}$ if $d_{v s}$ is in $\mu \mathrm{m}$, and $\rho$ is in $\mathrm{g} \mathrm{cm}^{-3}$.

\section{Determination of the amount of adsorbed protein}

Three separate samples (about $40 \mathrm{~mL}$ ) from each of ten freshly made emulsions produced under identical conditions to the centre points of the design (ie, $[$ Prof $]=1.5 \mathrm{wt} \%,[B O]=10 \mathrm{wt} \%$, $[G M S]=0.4 \mathrm{wt} \%, P=42.4 \mathrm{MPa}$ and $T=70^{\circ} \mathrm{C}$ ) were subjected to various centrifugation levels. These levels were $10000,12500,15000,17$ 500,20000 or $22500 \mathrm{rpm}$ for $30 \mathrm{~min}$, at $5{ }^{\circ} \mathrm{C}$ (model L8-70M, Beckman Instruments inc, Palo Alto, CA, USA). The rotor (type $30,5 \leq r \leq 10.5 \mathrm{~cm}$, Beckman Instruments Inc) was previously refrigerated at $5^{\circ} \mathrm{C}$ for $12 \mathrm{~h}$. After centrifugation, centrifuge tubes (model 3410-2539, Nalgene ${ }^{\boxplus}$ Ultratubes, Fisher Scientific, Montreal, PQ, Canada) contained a thin layer of floating material, a middle layer comprising the bulk of volume and a small pellet of sediment. After the middle layer and the sediment were carefully recovered by a syringe and a spatula, respectively, the sedimenting pellet was resuspended in the middle phase with a mortar. Samples of the resulting dispersion (denoted 1), as well as native emulsions (denoted 0 ) were then analysed for fat and nitrogen content. Fat content was evaluated by infrared analysis (model 133B, Milkoscan, Foss Electric, Hillerød, Denmark) according to a procedure derived from previous results (Remillard et al, 1993) and nitrogen was determined by the general Kjeldahl procedure (International Dairy Federation, 1986). From these analyses, the relative adsorbed protein fraction $\left(F_{\text {ads }} \%\right.$ ) was simply deduced from the following expression:

$$
F_{\text {ads }} \cong 100\left(1-\frac{[\text { Prot }]_{1}\left(1-\Phi_{0}\right)}{[\text { Prot }]_{0}}\right)
$$

where [Prot $]_{0}$ is the protein content of the native emulsion $(g / g)$, $[\text { Prot }]_{1}$ is the protein content in the subnatant $(\mathrm{g} / \mathrm{g})$, and $\phi_{0}$ is the fat content in the native emulsion. The measurement of $F_{a d s}$ is relative since it ignores about $1.5 \pm 0.5 \%$ of the original fat which is not removed from the lower phase after centrifugation. Furthermore, if the average size of fat globules changes with any of 
the processing variables, this will affect the amount of fat in the subnatant and hence will alter the $F_{\text {ads }}$ values. In other words, the conditions established for centrifugation and valid for one formulation may not be totally adequate for another. Nevertheless, and aware of this limitation, a centrifugation treatment of $26700 \mathrm{~g}$ for $30 \mathrm{~min}$ was applied to the entire experimental design. Beyond these conditions, even though the recovery of fat was not significantly improved, the adsorbed protein fraction slightly decreased. This slight decrease in $F_{a d s}$ could be due to the liberation of protein particles possibly entrapped in the oil matrix of the upper phase, and/or the removal of protein particles from the fat globule surface layer. It was under these centrifugation conditions $\left(26700 \mathrm{~g}\right.$ for $30 \mathrm{~min}$ at $5^{\circ} \mathrm{C}$ ) that the relative adsorbed protein fraction $\left(F_{\text {ads }}\right.$, eq [3]) and the protein load $\left(\Gamma, \mathrm{mg} \mathrm{m}^{-2}\right)$ were evaluated.

The latter was deduced from protein mass balances on the native emulsion and the resuspended phase obtained after centrifugation. The protein mass balance on the native emulsion (denoted 0 ) was given by:

$$
[\text { Prof }]_{0}=A_{\text {spo }_{0}} \Phi_{0} \Gamma+\left(1-\Phi_{0}\right)[\text { Prot }]_{2}
$$

where $A_{s p_{0}}$ is the specific surface area $\left(\mathrm{m}^{2} \mathrm{mg}^{-1}\right)$ of dispersed fat in the emulsion and $[\text { Prot }]_{2}$ is the protein content $(\mathrm{g} / \mathrm{g})$ of the plasma (denoted 2). As a small fat fraction remains in the subnatant after centrifugation (fig 1 ), a protein mass balance on the subnatant (denoted 1) must also be used:

$$
\left[\text { Prof }_{1}=A_{s D_{1}} \Phi_{1} \Gamma+\left(1-\Phi_{1}\right)\left[\text { Prof }_{2}\right.\right.
$$

where $A_{s p}$ is the specific surface area $\left(\mathrm{m}^{2} \mathrm{mg}^{-1)}\right.$ of dispersed fat in the subnatant and $\phi_{1}$ is its mass fat fraction. $\Gamma$ is obtained by substituting the analytical expression of [Prot $]_{2}$ (eq [4]), into eq [5], according to:

$$
\Gamma=\frac{\left[\operatorname{Prof}_{0}\left(1-\Phi_{1}\right)-\left[\operatorname{Prof}_{1}\left(1-\Phi_{0}\right)\right.\right.}{A_{s p_{0}} \Phi_{0}\left(1-\Phi_{1}\right)-A_{s p_{1}} \Phi_{1}\left(1-\Phi_{1}\right)}
$$

\section{Electron microscopy}

Six emulsions containing the same butter oil concentration (10 wt\%) and a variable GMS:protein molecular ratio $(0,1.9,5.6,11.2,55.9$ and $\infty)$ obtained by varying the monoglyceride concentration (from 0 to $1.5 \mathrm{wt} \%$ ) and keeping constant the protein concentration $(1.5 \mathrm{wt} \% \mathrm{ex}$ cept for emulsion 6 where $[$ Prof $]=0$ ) were micro- fluidized under the same emulsification conditions (at $42.4 \mathrm{MPa}$ and $70^{\circ} \mathrm{C}$ ). About 7 days after production, emulsion samples containing 0.02 wt $\%$ of sodium azide (Fisher Scientific, Quebec, $\mathrm{QC}$, Canada) were fixed by mixing equal volume of emulsion and $3 \%$ low melting-temperature agarose (Bio-Rad Laboratories, Richmond, CA, USA). After gelation on a porcelain plate, $\approx 1 \mathrm{~mm}^{3}$ cubes were excised and fixed in a $1 \%$ glutaraldehyde solution (JB EM Service, Pointe Claire, Dorval, QC, Canada) at $6{ }^{\circ} \mathrm{C}$ for $24 \mathrm{~h}$. The samples were then washed with distilled water and postfixed for $24 \mathrm{~h}$ at $6{ }^{\circ} \mathrm{C}$ in a $2 \%$ osmium tetroxide solution in a $0.05 \mathrm{~mol} \mathrm{~L}^{-1}$ veronal-acetate buffer, pH 6.85, containing $0.1 \mathrm{~mol} \mathrm{~L}^{-1}$ (Polysciences, Inc, Warrington, PA, USA) in order to retain liquids (Allan-Wojtas and Kalab, 1984). The samples were then dehydrated in a graded ethanol series, embedded in a Spurr's low viscosity medium (JB EM Services), and sectioned. Sections, $\approx 90 \mathrm{~nm}$ thick, were stained with uranyl acetate and lead citrate solutions (Reynolds, 1963) and examined in a Philips EM 300 electron microscope operated at $60 \mathrm{kV}$. Micrographs were taken on $35 \mathrm{~mm}$ film.

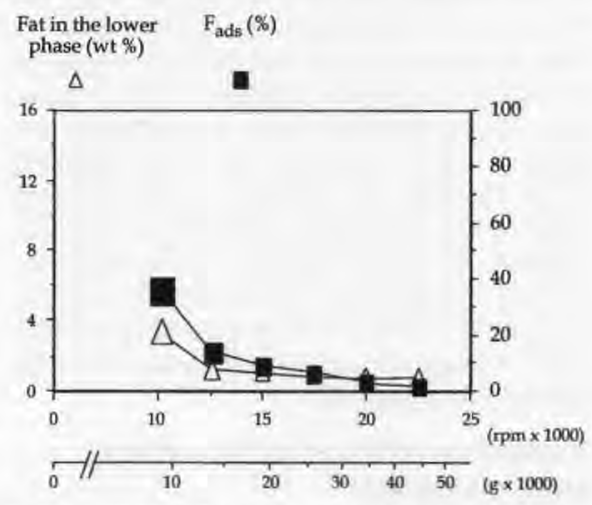

Fig 1. Influence of the centrifugal force expressed in rpm and $g$ (in the middle of the tube) on the fat content of the resuspended phase (fat, \%) and on the relative adsorbed protein fraction $\left(F_{\text {ads }} \%\right)$ after $30 \mathrm{~min}$ of centrifugation. The size of the symbols used roughly indicates the reproducibility of measurements.

Influence de la force centrifuge exprimée en rpm et en g (dans le milieu du tube) sur la teneur en matière grasse de la phase inférieure $(f a t, \%)$ et sur la fraction de protéines adsorbées $\left(F_{\text {ads }}, \%\right)$ après 30 minutes de centrifugation. La taille des symboles utilisés indique grossièrement la reproductibilité des mesures. 


\section{Statistical analysis}

An analysis of variance and regression calculations on protein surface concentration parameters $\left(F_{\text {ads }}\right.$ and $\left.\Gamma\right)$ were carried out using a linear model procedure (SAS, 1990). The nullity of the regression coefficients was tested using a Student test. An adjustment test was used to confirm that the second-order model allowed an adequate description (to $\pm 1 \%$ ) of the variations of the experimental results. Further details on the statistical analysis of this experimental design may be found elsewhere (Robin et al, 1992).

\section{RESULTS}

\section{The influence of formulation and process variables on the protein surface concentration}

Two analyses of variance were carried out on the values of protein surface concentrations $\left(F_{\text {ads }}\right.$ and $\left.\Gamma\right)$ using comparisons between the principal treatments and between the interactions. From these analyses and an Ftest, which differentiated the treatments and interactions having a significant effect on $F_{a d s}$ and $\Gamma$, two regression equations were deduced. Finally, an adjustment test was used to evaluate the fitting of experimental results to a secondorder polynomial model. Further details may be found in the first study (Robin et al, 1992).

\section{Relative adsorbed protein fraction $\left(F_{\text {ads }}, \%\right)$ in emulsion}

Table I shows the analysis of variance of the relative adsorbed protein fraction $\left(F_{\text {ads }}\right)$ as a function of process and formulation variables. According to the adjustment test, for $P \leq 0.01$ ( $F<4.77$ ), a second-order polynomial model adequately described the variance of the adsorbed protein fraction $\left(\sigma_{\text {Fads }}\right)$. As expected, composition factors had major effects on $F_{\text {ads }}$ since caseinates (sum of linear and quadratic effects), butter oil and monoglyceride concentrations explained $51.0,26.0$ and $12.3 \%$ of $\sigma_{\text {Fads, }}$ respectively. The emulsification pres- sure and temperature represented 1.2 and $2.2 \%$ of $\sigma_{\text {Fads }}$, respectively. Finally, among all the possible interaction effects, only the quadratic effect of protein concentration $\left(\left[\right.\right.$ Prof $\left.{ }^{2}\right)$ significantly influenced $\sigma_{\text {Fads. }}$. The regression equation calculated from these significant effects $(P \leq 0.05)$ explained $92.7 \%$ of $\sigma_{\text {Fads. }}$. All the coefficients were highly significant $(P \leq 0.001)$.

Figures $2 A$ and $B$ display the response surfaces obtained from the second-order model for process and formulation variables in the range of the study. In Figure 2A the values of $F_{\text {ads }}(\%)$, for a fixed temperature $\left(50^{\circ} \mathrm{C}\right)$ and for fixed caseinates $(1.5$ $w t \%)$ and monoglyceride (0.4 wt \%) concentrations, are expressed as a function of the butter oil concentration ([BO], $w t \%)$ and the emulsification pressure $(P$, $\mathrm{MPa})$. Since the adsorbed protein fraction $\left(F_{a d s}\right)$ is directly proportional to the total fat surface area, any increase in emulsification pressure and/or butter oil concentration favours caseinate adsorption and increases $F_{\text {ads }}$ values (fig 2A). Nevertheless, this last statement is only true if the fat is mainly found in the upper layer. In emulsions containing 0.4 wt $\%$ of monoglycerides, adsorbed protein fractions $\left(F_{a d s}\right)$ ranged from $\approx 1$ to $\approx 13 \%$ (fig $2 A$ ), which is drastically lower than those found in emulsions stabilized only by proteins. Indeed, in the absence of monoglycerides ([Prof $]=1.5$ $w t \%), F_{a d s}=87 \%$ for an emulsion produced under identical conditions to the centre points (ie, $[B O]=10 \mathrm{wt} \%, P=42 \mathrm{MPa}$ and $T=70^{\circ} \mathrm{C}$ ) (fig $3 \mathrm{~A}$ ). This result is in good agreement with those of other authors. For example, Oortwijn and Walstra (1979) and Courthaudon et al (1991b) found, under different homogenization conditions, that all of the protein emulsifier was adsorbed at the oil droplet surface in emulsions. Their emulsions were respectively made with either skimmed milk or whey, or $\beta$-casein (0.4 wt\%, $20 \mathrm{wt} \% n$-hexadecane, $\mathrm{pH} 7.0$ ). Finally, electron micrographies $1 A$ and $B$ (photo 1), corresponding to the emulsion 

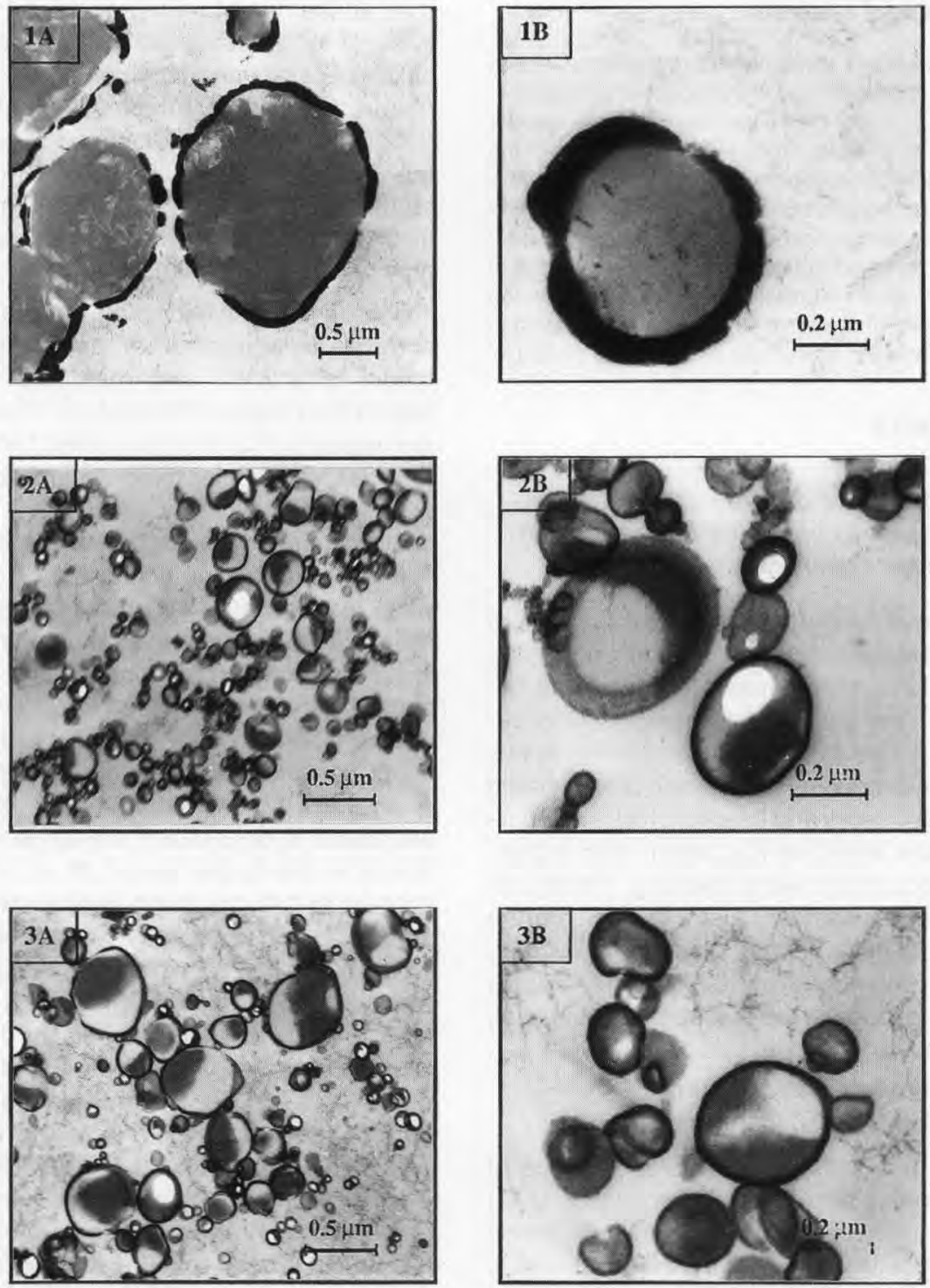

Photo 1. Electron micrographs of various microfluidized emulsions. The GMS:protein molecular $(R)$ was increased by varying [GMS] while the other conditions remained constant ([Prot] $=1.5 \mathrm{wt} \%$, $[B O]=10 \mathrm{wt} \%, P=50 \mathrm{MPa}$ and $T=70^{\circ} \mathrm{C}$ ). If not specified, magnifications were $9030 \mathrm{x}$ and 24580 $\mathrm{x}$ for the $\mathrm{A}$ and $\mathrm{B}$ series, respectively. (1) $R=0, \mathrm{~A} \times 7190$; (2) $R=1.9$ and (3) $R=5.6$.

Photographies de microscopie électronique pour diverses émulsions microfluidisées. Le ratio moléculaire GMS: protéine (R) a été augmenté en faisant varier [GMS], les autres conditions expérimentales restant inchangées [Prot] $=1,5 \%,[B O]=10 \%, P=50 \mathrm{MPa}, T=70^{\circ} \mathrm{C}$ ). En l'absence de spécification contraire, les grossissements utilisés étaient respectivement de $9030 \times$ et de $24580 \times$ pour les séries A et $B$. (1) $\mathrm{R}=0, A \times 7190$; (2) $\mathrm{R}=1,9$, et (3) $\mathrm{R}=5,6$. 
free of monoglycerides, show milkfat globules with very thick protein membranes which illustrates a high sodium caseinate adsorption on the globule surface. In these electron micrographs, the adsorbed layers of proteins were about 45 to $60 \mathrm{~nm}$ thick.

The adsorbed caseinate fraction decreased with increasing emulsification temperature. This decrease was about $3.9 \% / 10{ }^{\circ} \mathrm{C}$ between 35 and $100^{\circ} \mathrm{C}$ (table l). A similar tendency was also reported by Walstra (1975) and Oortwijn and Walstra (1979) with skimmed milk.

The influence of emulsifier type and concentration on the adsorbed protein frac- tion $\left(F_{a d s}\right)$ is presented in figure 2B where $F_{\text {ads }}$ is plotted against the surfactant ([Prof] and [GMS]) concentrations for a fixed butter oil concentration (10 wt\%) and for fixed emulsification pressure $(40 \mathrm{MPa})$ and temperature $\left(50^{\circ} \mathrm{C}\right)$. As expected, when sodium caseinates were present, any increase in [GMS] induced a proportional decrease in $F_{\text {ads. }}$ On the contrary, when monoglycerides were present, an increase in [Prof] only induced a slight increase in the amount of adsorbed proteins, which eventually rapidly leveled off. These results suggest that because monoglycerides are more surface active, they first accumulate
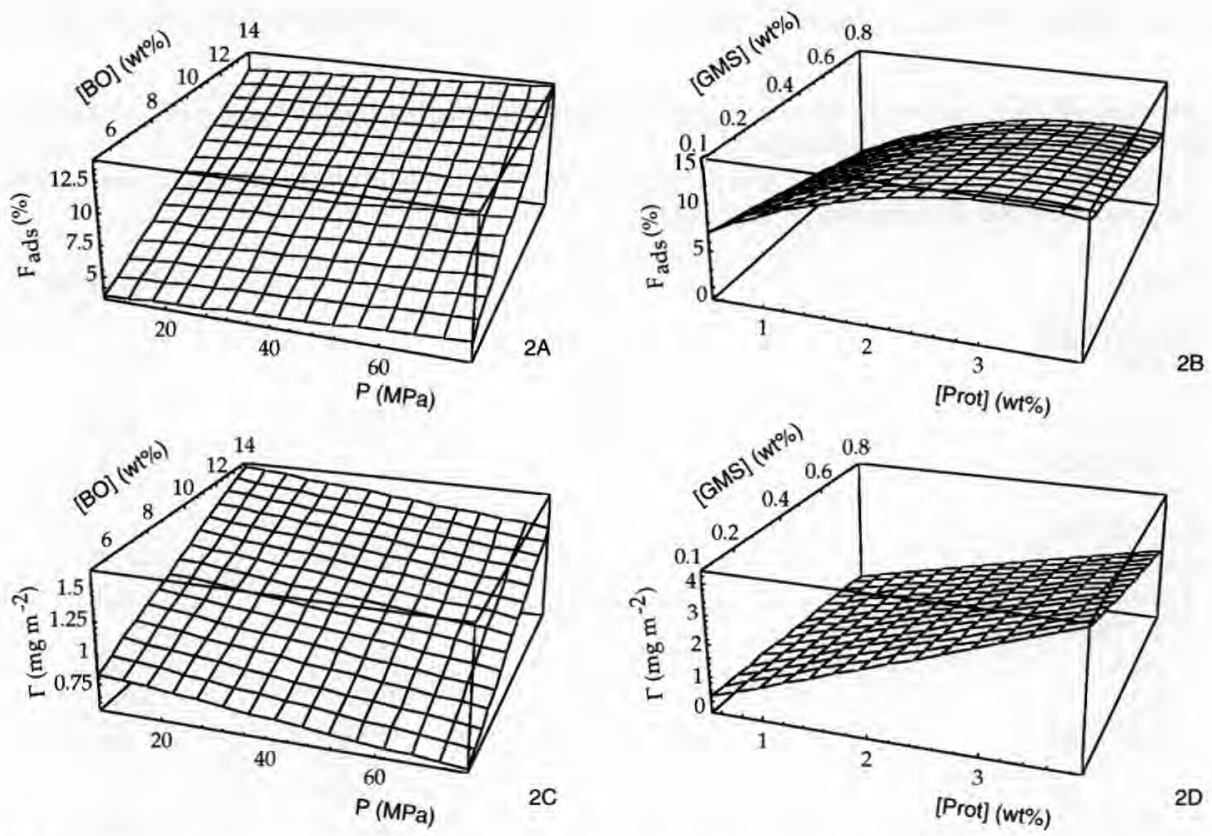

Fig 2. Response surfaces relating the values of adsorbed protein fraction $\left(F_{\text {ads }}\right)$ and protein load $(\Gamma)$ as a function of the butter oil concentration $([B O)$ and the emulsification pressure $(P)(A$ and $B$, respectively), and as a function of emulsifier type and concentration ([Prot] and [GMS]) (C and D, respectively). The other variables were fixed $\left(T=70^{\circ} \mathrm{C},[\right.$ Prot $]=1.5 \mathrm{wt} \%,[G M S]=0.4 \mathrm{wt} \%$ and $/$ or $P=50 \mathrm{MPa},[B O]=10 \mathrm{wt} \%$ ).

Surfaces de réponse reliant les valeurs de $\mathrm{F}_{\mathrm{ads}}$ et $\Gamma$ à la concentration en huile de beurre ([BO]) et la pression d'émulsification (P) ( $A$ et $B$, respectivement), et à la nature et la concentration des émulsifiants (Prot] et [GMS] (C et $D$, respectivement). Les autres variables étaient fixées $\left(T=70^{\circ} \mathrm{C}\right.$, $[$ Prot $]=1,5 \%,[\mathrm{GMS}]=0.4 \%$, et ou $\mathrm{P}=50 \mathrm{MPa},[\mathrm{BO}]=10 \%)$. 
at the interface, leaving little free space to proteins. Protein adsorption is then rapidly limited. This hypothesis is partly confirmed by the electron micrographs [photos 1 (2A to $3 B$ ) and 2] since distinctly finer milkfat globule membranes (about $15 \mathrm{~nm}$ ) were observed at GMS:protein molecular ratio $(R)$ as low as 1.9. A regression analysis was finally carried out on the $F_{\text {ads }}$ values as a function of $R,[B O], P$ and $T$. The obtained relationship, between $F_{\text {ads }}$ and $R$, appears to fit an exponentially decreasing function of $R$ (fig $3 \mathrm{~A}$ ). Although this form of curve seems to describe a rather simple mechanism of competitive adsorption, it should be considered as a rough approximation since this relationship only explains $77 \%$ of the total variance of $F_{a d s}$, compared to more than $90 \%$ when the five process and formulation variables are used.

\section{Protein load $\left(\Gamma, \mathrm{mg} \mathrm{m}^{-2}\right)$ of the microfluidized fat globules}

Table II shows the analysis of variance of the protein load $(\Gamma)$ as a function of compositional and process variables. According to the adjustment test, a second-order polynomial model adequately described the variance of the protein load $\left(\sigma_{\Gamma}\right)$ within the range of the study. As previously mentioned, the linear effects of the principal factors were highly significant (more than $95 \%$ ). The protein concentration, as expected from eq [6], had a major effect on $\Gamma$ since it explained more than $87 \%$ of $\sigma_{\Gamma}$. The butter oil and monoglyceride concentrations

Table I. Analysis of variance and second-order model of the adsorbed protein fraction ( $\left.F_{\text {ads }}, \%\right)$ versus formulation and process parameters.

Analyse de variance et modèle de second ordre de la fraction protéique adsorbée $\left(F_{\text {ads }} \%\right)$ en fonction des paramètres de composition et de procédé.

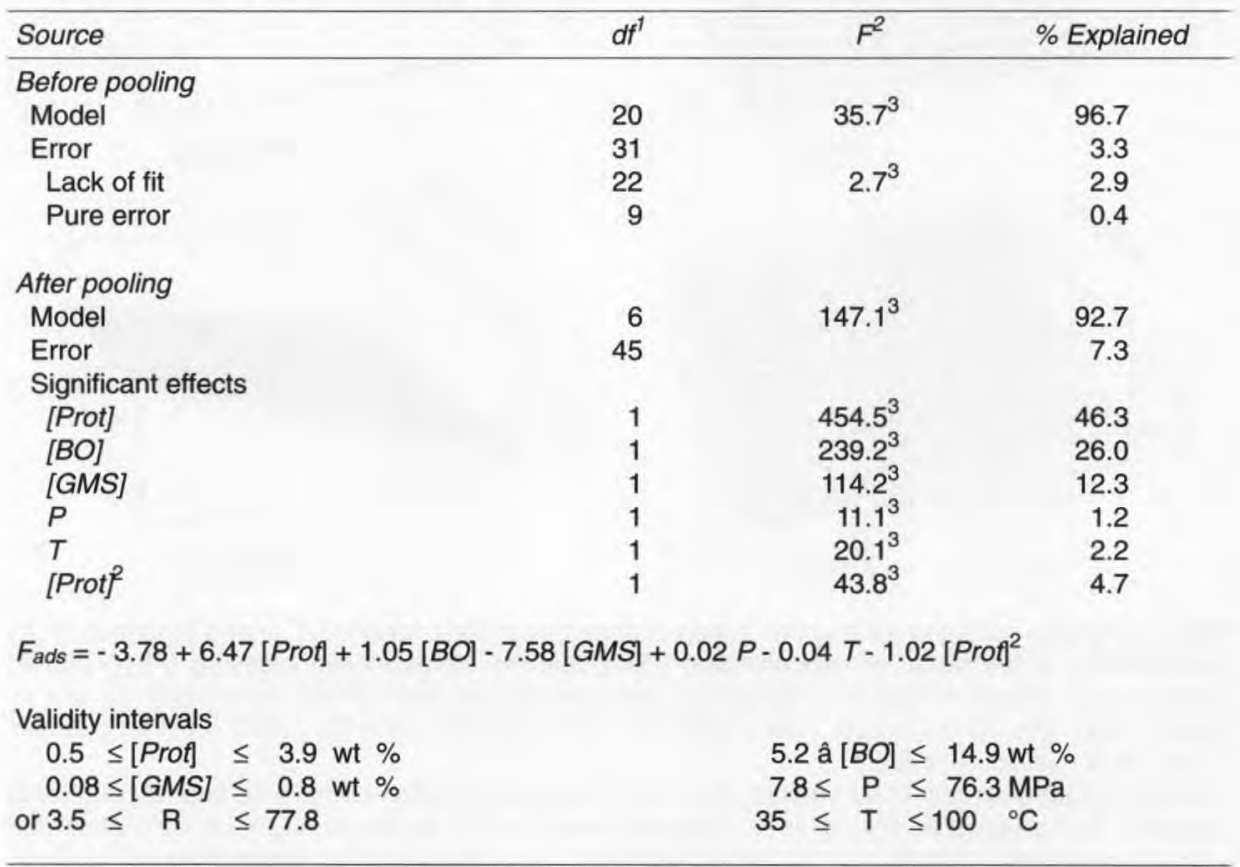

\footnotetext{
${ }^{1} \mathrm{df}$ : degree of freedom; ${ }^{2} \mathrm{~F}$ : Fisher ratio; ${ }^{3} P<0.001$.
} 
explained 3.6 and $5.5 \%$ of $\sigma_{\Gamma}$, respectively. The influence of process factors, although having minor effects on $\sigma_{\Gamma}$, was nevertheless significant. The emulsification pressure and temperature respectively accounted for 1.1 and $1.6 \%$ of $\sigma_{\Gamma}$. The last significant effect, according to the analysis of variance, was the $[$ Prof $] \times[G M S]$ interaction. It explained $1.1 \%$ of $\sigma_{\Gamma}$. Other effects were not significant $(P>0.05)$; the error term represented approximately $9.4 \%$ of $\sigma_{\Gamma}$. The regression equation (table II) calculated from these significant effects $(P$ 0.05 ) explained $90.6 \%$ of $\sigma_{\Gamma}$. All the coefficients were highly significant $(P \leq 0.001)$.

Figure $2 \mathrm{C}$ is the response surface obtained from a second-order model relating the values of $\Gamma\left(\mathrm{mg} \mathrm{m}^{-2}\right)$ as a function of butter oil concentration ([BO], wt\%) and of emulsification pressure $(P, \mathrm{MPa})$, for a fixed temperature $\left(50{ }^{\circ} \mathrm{C}\right)$ and for fixed protein (1.5 wt\%) and monoglyceride concentrations $(0.4 \mathrm{wt} \%)$. As with $F_{\text {ads }}$ values, an increase in butter oil concentration, by increasing the average diameter of fat globules (Robin et al, 1992), lead to a reduction in specific surface area $\left(A_{s p}\right)$, which enhances $\Gamma$. On the contrary, an increase in emulsification pressure induced a considerable increase in $A_{s p}$ and led to a slight but significant decrease of $\Gamma$. The increase in $A_{s p}$ was about $74 \%$ for a pressure increase from 10 to $60 \mathrm{MPa}$ ([Prof $]=1.5$ $\mathrm{wt} \%,[B O],=10 \mathrm{wt} \%,[G M S]=0.4 \mathrm{wt} \%$ and

Table II. Analysis of variance and second-order model of the protein load $\left(\Gamma, \mathrm{mg} \mathrm{m}^{-2}\right)$ versus formulation and process parameters.

Analyse de variance et modèle de second ordre de la charge protéique $\left(\Gamma, \mathrm{mg} \mathrm{m}^{-2}\right)$ en fonction des variables de formulation et de procédés.

\begin{tabular}{|c|c|c|c|}
\hline Source & $d f^{1}$ & $F^{2}$ & $\%$ Explained \\
\hline \multicolumn{4}{|l|}{ Before pooling } \\
\hline Model & 20 & $88.6^{3}$ & 98.0 \\
\hline Error & 31 & & 2.0 \\
\hline Lack of fit & 22 & $4.7^{3}$ & 1.5 \\
\hline Pure error & 9 & & 0.5 \\
\hline \multicolumn{4}{|l|}{ After pooling } \\
\hline Model & 6 & $112.6^{3}$ & 90.6 \\
\hline Error & 45 & & 9.4 \\
\hline \multicolumn{4}{|l|}{ Significant effects } \\
\hline [Prot] & 1 & $586.0^{3}$ & 87.7 \\
\hline$[\mathrm{BO}]$ & 1 & $25.9^{3}$ & 3.6 \\
\hline [GMS] & 1 & $39.4^{3}$ & 5.5 \\
\hline$P$ & 1 & $5.6^{3}$ & 1.1 \\
\hline$T$ & 1 & $11.7^{3}$ & 1.6 \\
\hline$[$ Prof $] \times[G M S]$ & 1 & $8.1^{3}$ & 1.1 \\
\hline \multicolumn{4}{|c|}{$\Gamma=-0.35+1.19[$ Prot $]+0.09[B O]-0.29[\mathrm{GMS}]-0.004 P-0.008 T-0.60[$ Prot $] \times[\mathrm{GMS}]$} \\
\hline \multicolumn{4}{|l|}{ Validity intervals } \\
\hline $0.5 \leq[$ Prot $] \leq 3.9$ wt $\%$ & & 5.2 â $[B O]$ & \\
\hline $0.08 \leq[G M S] \leq 0.8$ wt $\%$ & & $7.8 \leq P$ & \\
\hline or $3.5 \leq R \leq 77.8$ & & $35 \leq T \leq$ & \\
\hline
\end{tabular}

${ }^{1} \mathrm{df}:$ degree of freedom; ${ }^{2} \mathrm{~F}$ : Fisher ratio; ${ }^{3} P<0.001$. 
$T=70^{\circ} \mathrm{C}$ ). A similar pressure effect on $\Gamma$ values was also reported on protein-stabilized emulsions by Tornberg (1978).

Although the temperature effect on the amount of adsorbed proteins was similar to that affecting $F_{a d s}$ values, its magnitude was higher: the decrease of $\Gamma$ as a function of $T$ was about $5.8 \% / 10^{\circ} \mathrm{C}$ between 35 and $100^{\circ} \mathrm{C}$. A decrease in $\Gamma$ from 10.7 to
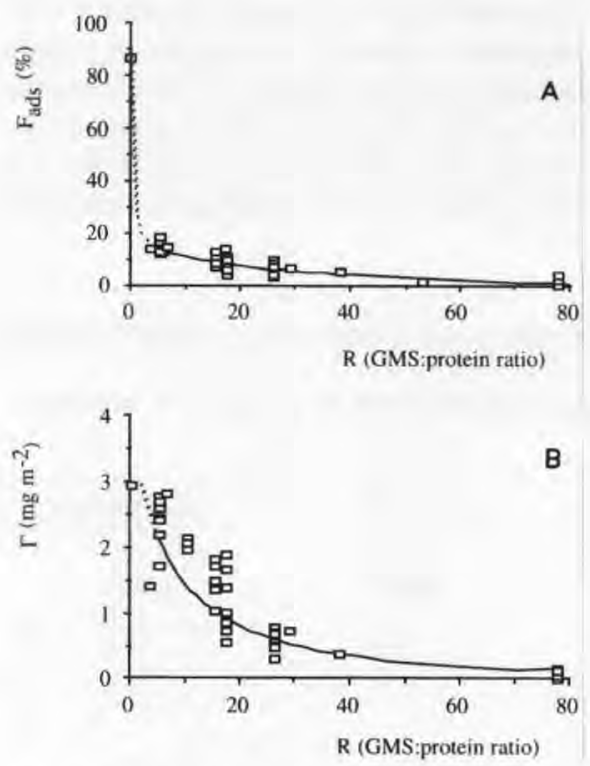

Fig 3. Effect of the GMS:protein molecular ratio $(R)$ on the protein surface concentration expressed in terms of $(A)$ adsorbed protein fraction $\left(F_{\text {ads }}, \%\right)$ and $(\mathrm{B})$ protein load $\left(\Gamma, \mathrm{mg} \mathrm{m}^{-2}\right)$. (D) are the 52 experimental points: 24 and 12 points are hidden in (A) and (B), respectively. $(-)$ are the theoretical curves determined by an analysis of regression between $F_{\text {ads }}$ or $\Gamma$ and $R,[B O], P$, $T$ and their significant interactions.

Effet du ratio moléculaire GMS:protéine (R) sur la concentration de protéines en surface, exprimée soit sous forme de (a) fraction adsorbée $\left(F_{\text {ads }}, \%\right)$, ou (b) charge protéique $\left(\Gamma, \mathrm{mg} \mathrm{m}^{-2}\right)$. (]) sont les 52 points expérimentaux dont 24 et 12 sont respectivement masqués dans (A) et (B). $(-)$ sont les courbes théoriques obtenues par une analyse de régression entre $F_{\text {ads }}>$ ou $\Gamma$, et $\mathrm{R},[\mathrm{BO}], \mathrm{P}, \mathrm{T}$, et leurs interactions significatives.
$6.0 \mathrm{mg} \mathrm{m}^{-2}$ due to a temperature increase from 40 to $60{ }^{\circ} \mathrm{C}$ (about $22 \% / 10^{\circ} \mathrm{C}$ ) was also reported for recombined milk (Oortwijn and Walstra, 1979).

Figure 2D shows the influence of sodium caseinates and monoglyceride concentrations on the amount of adsorbed proteins on fat globules per unit of area $\left(\Gamma, \mathrm{mg} \mathrm{m}^{-2}\right)$ for a fixed butter oil concentration (10 $w t \%)$ and for fixed emulsification pressure (40 $\mathrm{MPa})$ and temperature $\left(50^{\circ} \mathrm{C}\right)$. In emulsions containing as low as 0.08 wt $\%$ of monoglycerides, $\Gamma$ ranged from 0.5 to $4 \mathrm{mg} \mathrm{m}^{-2}$ for $0.5 \leq[$ Prof $] \leq 3.9 \mathrm{wt} \%$. In the absence of monoglycerides, the protein load was $2.9 \pm 0.2 \mathrm{mg} \mathrm{m}^{-2}$ for an emulsion produced under identical conditions to the centre points (ie, [Prof] $=1.5 \mathrm{wt} \%$, $[B O]=10 \mathrm{wt} \%, P=42 \mathrm{MPa}$ and $T=70^{\circ} \mathrm{C}$ ). This value is consistent with that found for $\beta$-casein adsorbed at the planar oil-water interface (Graham and Phillips, 1979) and in various casein or NaCas-stabilized emulsions (Tornberg, 1978; Walstra and Oortwijn, 1982; Courthaudon et al, 1991b). Lower values $(0.8 \leq \Gamma \leq 1.2 \mathrm{mg} \mathrm{m}-2)$ were also reported in a $10 \mathrm{wt} \%$ soybean emulsion, 0.5 wt $\%$ casein, Tris- $\mathrm{HCl}$ buffer (Dickinson et al, 1993). Even though increases in [GMS] lead to decreases in $\Gamma$ at any given [Prof] (fig 2D), the $\Gamma$ increase remained proportional to [Prot], which is different from the effect of [Prof] on $F_{\text {ads }}$ (fig 2C). Finally and as previously done, a regression analysis was carried out on the $\Gamma$ values as a function of $R,[B O], P$ and $T$. From statistical analysis a decreasing exponential relationship between $\Gamma$ and $R$ was obtained, explaining about $70 \%$ of $\sigma_{\Gamma}$ (fig 3B). These figures compare well the behaviour of systems made of $\beta$-casein, with or without $\alpha_{s 1}$-casein, and zwitterionic surfactants, such as phosphatidylcholine (Courthaudon et al, 1991a) or monoglycerides (Dickinson et al, 1993; Tomas et al, $1994 b)$ at $n$-alkane or triglycerides interfaces. Although comparisons must be made with caution, exponential decreasing 
behaviour, between $\Gamma$ and $R$ for $4.5 \leq R$ $\leq 100$, was also reported by Dickinson et al (1993) and Tomas et al (1994a, b). However, they do not seem to agree with the results that are found using electron microscopy. Indeed, if the values of $\Gamma$ are both around $3 \mathrm{mg} \mathrm{m}^{-2}$ for $R=0$ and $R=1.9$, the estimated thickness from micrographies suggests a difference in load of about a factor 4 .

\section{DISCUSSION}

The homogenization process induces both a decrease in the average size of fat globules and in the spread of distribution that lead to the creation of a large new fat-serum interface, and the development of a new membrane. In dairy emulsions, this membrane is represented by the material adsorbed at the interface between the fat and serum phases. It contains essentially caseins, in the case of homogenized milk or cream (Darling and Butcher, 1978; Oortwijn and Walstra, 1979; Dalgleish, 1994), or both proteins and low molecular mass surfactants, as suggested by various works of Pr Dickinson's research group. During homogenization, parameters which characterize protein adsorption are mainly influenced by the emulsification pressure and temperature (Walstra and Oortwijn, 1982), the fat concentration (Walstra et al, 1984), the protein nature and concentration ( $\mathrm{Le}$ man and Kinsella, 1989; Britten and Giroux, 1993) and by the presence of surfactants (Dickinson and Woskett, 1989).

\section{Accuracy and reproducibility of the protein surface concentration measurements}

In theory, the centrifugation methods at medium-high speed would be appropriate to evaluate the protein surface concentration if emulsions are stable against coalescence and free of very small fat globules, and if proteins suspended in the aqueous phase do not sediment. In practice however, it is a bit different. Indeed, the centrifugation of oil-in-water dairy emulsions generally leads to a separation into three layers: a thin layer of floating material, a middle layer comprising the bulk of the volume and a sediment. The physicochemical characteristics of these three layers depend on the centrifugation conditions. Dalgleish and Robson (1985), studying various sedimenting pellets obtained from centrifugal fractionations of homogenized milks, have shown that the fat:protein ratio as well as the milkfat globule diameter increased as the centrifugation force was increased. Similar trends have also been reported by Blanchot (1992) when studying the centrifugation behaviour of the same model emulsions as those used in this study. Some conclusions can be drawn from these results. First, it seems clear that variable proportions of proteins adsorbed or accumulated on fat globules and proteins in solution co-sediment. Second, the protein concentration on fat globules varies with the fat globule diameter; this was confirmed by dissociating proteins with EDTA. These results, which partly reflect structural differences between centrifuged particles, must necessarily have repercussions on the evaluation of the relative $F_{\text {ads. }}$. If the average reproducibility of measurements for $F_{\text {ads }}$ was satisfactory $( \pm 2.7 \%)$, it was estimated by Blanchot (1992) that approximately $2-5 \%$ (depending on the processing variables) of adsorbed proteins on sedimented fat globules were not taken into account in evaluating $F_{\text {ads. }}$.

According to this procedure, the estimation of the protein load $(\Gamma)$ rests both on the determination of the interfacial area obtained from the average diameter of dispersed particles, and on a protein mass balance. Without lingering on a previous discussion (Robin et al, 1992), the average diameter obtained by laser light scattering is not a simple average. It depends upon the amount of light scattered at $90^{\circ}$ by all 
the particle sizes in a given sample, that is, upon the range of the particle size distribution. Furthermore, eq [5] which describes the protein mass balance in phase 1 (middle phase and sedimenting pellet), assumes that $\Gamma$ is the same for all fat globules. In homogenized milks, Oortwijn and Walstra (1979) have clearly shown that $\Gamma$ was higher for smaller globules. To take this difference into account, they introduced a correction factor into eq [6]. In the present study, as in others (Hunt and Dalgleish, 1994), we have no reason to believe that the adsorbed protein concentration is dependent on size.

\section{The influence of process variables on the protein surface adsorption ( $F_{a d s}$ and $\Gamma$ )}

\section{The effect of emulsification pressure}

High energy densities generated during microfluidization increase both the collision number between proteins and fat globules and the fat globule dispersion. The former enhances the protein adsorption $\left(F_{a d s}\right)$ even though the latter reduces the amount of adsorbed proteins per unit of area ( $\Gamma)$. A different result, that is, an increase of $\Gamma$ with $P$, was reported in milk, however (Walstra et al, 1984). This result may be due both to the milk emulsion itself and to the protein transport toward the fat during emulsification. The latter is roughly proportional to the protein concentration, and $\left(d_{g}+d_{p}\right)^{3}$, where $d_{g}$ and $d_{p}$ denote fat globule and protein particle diameter, respectively (Walstra and Oortwijn, 1982). From the previous relationship and if proteins are relatively abundant, which is the case in milk, the smallest fat globules have on average a higher surface layer; consequently, $\Gamma$ may increase with $P$.

\section{The effect of emulsification temperature}

The actual protein load and membrane composition are affected by the emulsification temperature. This variable induced a decrease in the protein adsorption parame- ters ranging from about 4 to $6 \% / 10^{\circ} \mathrm{C}$ for $F_{a d s}$ and $\Gamma$, respectively. Two influences might explain this decrease. First, increases in emulsification temperature induced a strengthening of hydrophobic interactions (at least up to $60-65^{\circ} \mathrm{C}$ ) and a weakening of the molecular structure of water, both of which may have favoured the adsorption of monoglycerides. Second, an increase in the emulsification temperature induced an increase in the spreading rate of proteins at the oil-water interface, and consequently led to a reduction in $\Gamma$ values, as suggested by Oortwijn and Walstra (1979).

\section{The influence of compositional factors on the protein surface adsorption ( $F_{\text {ads }}$ and $\Gamma$ )}

\section{The effect of butter oil concentration}

Any increase in the butter oil concentration increases the amount of adsorbent material, and the average fat globule diameter. Two hypotheses might explain the increase of the protein adsorption parameters $\left(F_{\text {ads }}\right.$ and $\Gamma$ ) with the butter oil content (fig $2 A$ and C). The first is classical. Any increase in the $[B O]$ enlarges the total surface area $\left(A_{t}\right)$ of the milkfat membrane, ie, the free space at the interface that favours protein adsorption $\left(F_{a d s}\right)$. Furthermore, by leading to a drop in the specific surface area $\left(A_{s p}\right)$, since the average fat globule diameter increases (eq [2]), the increase of $[B O$ ] also has a positive and a mathematical effect on $\Gamma$ (eq [6]). The second, though more, must be mentioned. The increase in the fat globule diameter in the butter oil fraction might not be caused by a less efficient emulsification, but rather by some recoalescence favoured by the high frequency of droplet collisions in the emulsification chamber. In this case, the reduction of the interfacial area which occurs during recoalescence induces a compression of the protein film, which then enhances $\Gamma$. This effect was initially reported by Pearce and Kinsella 


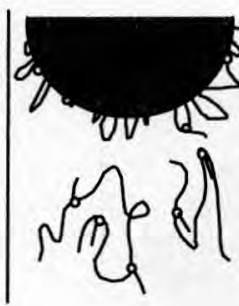

d

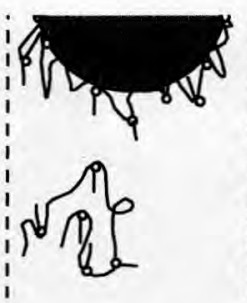

d

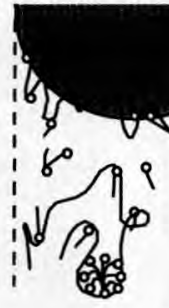

d

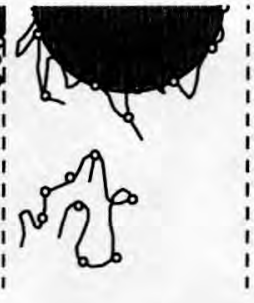

d

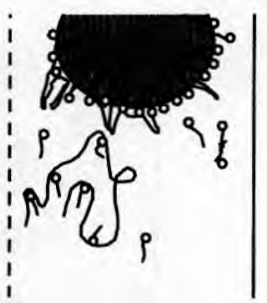

d

$\mathrm{R}$

$\stackrel{F_{\text {ads }} \text { and } \Gamma}{\longleftarrow}$

Fig 4. Schematic representation of the protein-monoglyceride competitive adsorption effects on fat globules as a function of $d$ (average particle size), $R$ (GMS:protein molecular ratio), $F_{\text {ads }}$ (adsorbed protein fraction), and $\Gamma$ (protein load). Fat is represented by the shaded grey area (inspired from Dickinson and Woskett, 1989; adapted from Robin et al, 1993).

Représentation schématique de l'effet de l'adsorption compétitive protéine-monoglycéride sur le globule gras en fonction de d (diamètre particulaire moyen), R (ratio moléculaire GMS:protéine), $\mathrm{F}_{\text {ads }}$ (fraction de protéines adsorbées), et $\Gamma$ (charge protéique). La matière grasse est représentée par les zones ombragées en gris (inspiré de Dickinson et Woskett, 1989; adapté de Robin et al, 1993).
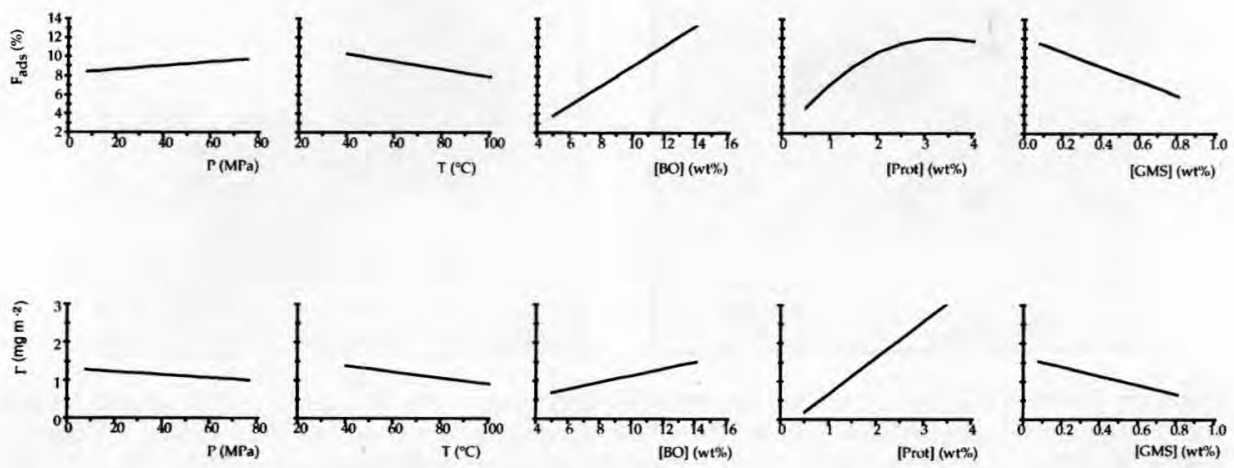

Fig 5. Effects of process and composition variables on the protein adsorption parameters $\left(F_{a d s}\right.$ and $\Gamma)$. For each graph, values of four variables were either specified or fixed. In the latter case, their values were $P=50 \mathrm{MPa}, T=70^{\circ} \mathrm{C},[B O]=10 \mathrm{wt} \%,[$ rot $]=1.5 \mathrm{wt} \%$ and $[G M S]=0.4 \mathrm{wt} \%$.

Effets des variables de procédés et de composition sur les paramètres de l'adsorption protéique. Pour chaque figure, les valeurs des quatre variables étaient soient spécifiées, soient fixées. Dans ce dernier cas, leur valeur était : $\mathrm{P}=50 \mathrm{MPa}, \mathrm{T}=70^{\circ} \mathrm{C},[\mathrm{BO}]=10 \%$, [Prot $]=1,5 \%$ et $[\mathrm{GMS}]=0,4 \%$. 

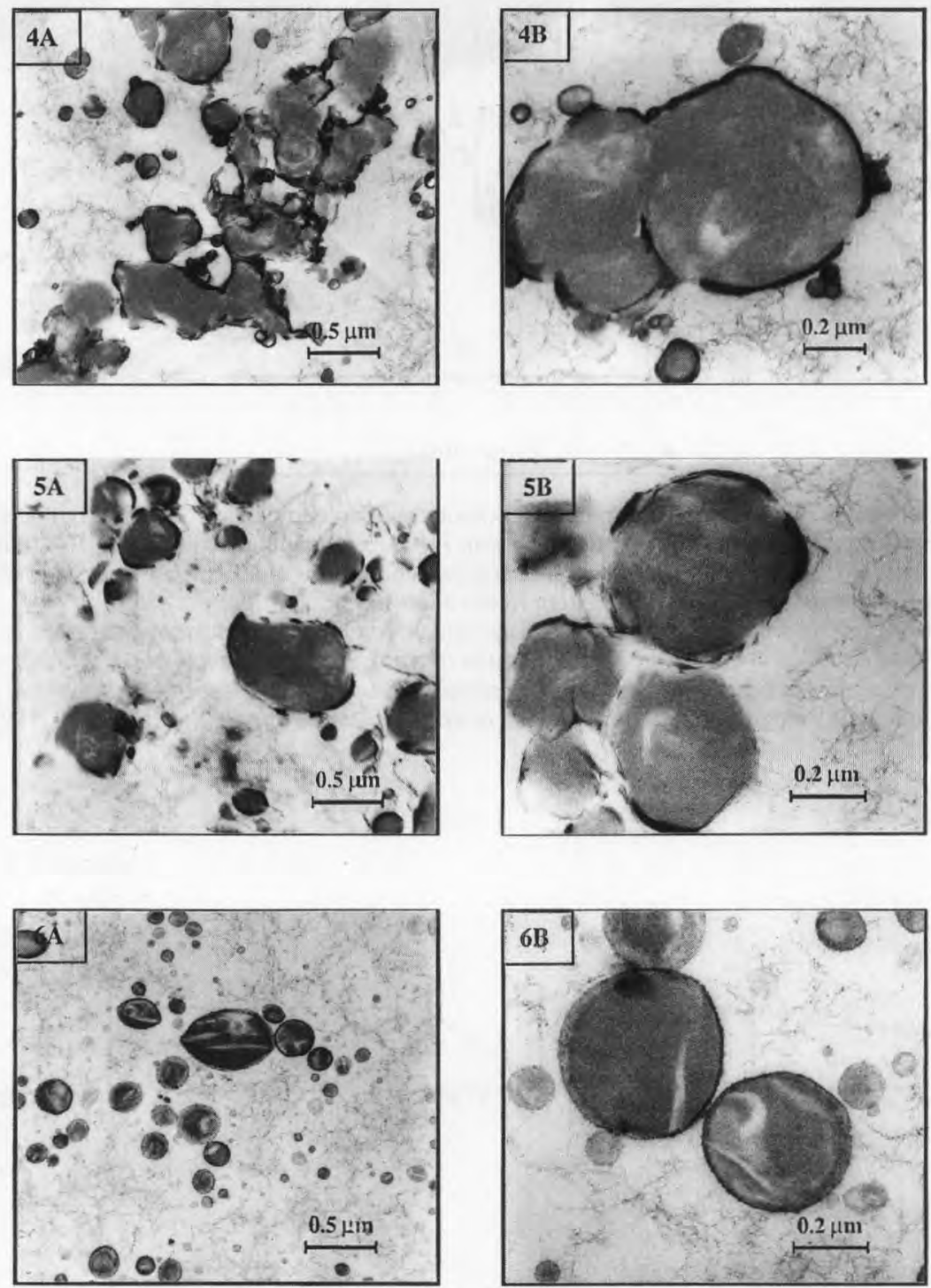

Photo 2. Electron micrographs of various microfluidized emulsions. The GMS:protein molecular $(R)$ was increased by varying [GMS] while the other conditions remained constant ([Prot] $=1.5 \mathrm{wt} \%$, $[B O]=10 \mathrm{wt} \%, P=50 \mathrm{Mpa}$ and $T=70^{\circ} \mathrm{C}$ ). If not specified, magnifications were $9030 \times$ and 24580 $\mathrm{x}$ for the A and B series, respectively. (1) $R=11.2, \mathrm{~B} \times 19200$; (2) $R=55.9$ and (3) $R=\infty$.

Photographies de microscopie électronique pour diverses émulsions microfluidisées. Le ratio moléculaire GMS:protéine (R) a été augmenté en faisant varier [GMS], les autres conditions expérimentales restant inchangées $[$ Prot $]=1,5 \%,[\mathrm{BO}]=10 \%, \mathrm{P}=50 \mathrm{MPa}, \mathrm{T}=70^{\circ} \mathrm{C}$ ). En l'absence de spécification contraire, les grossissements utilisés étaient respectivement de 9030 x et de 24580 x pour les séries A et $B$. (1) $R=11,2, B \times 19200$; (2) $R=55,9$, et (3) $R=\infty$. 
(1978) while studying peanut oil-in-water emulsions stabilized by whey proteins.

\section{The effect of surfactant concentrations}

When fat globules are entirely covered with a layer of completely spread protein molecules (the cross-sectional area per amino acid residue is about $15.3 \AA^{2}$ ), an approximate calculation shows that the protein load $(\Gamma)$ of milkfat globules would theoretically be about $1.2 \mathrm{mg} \mathrm{m}^{-2}$. With a single layer of casein submicelles, $\Gamma$ would be about $5.5 \mathrm{mg} \mathrm{m}^{-2}$ and about $41.3 \mathrm{mg} \mathrm{m}^{-2}$ with a single layer of whole casein micelles. All the intermediate situations may also occur, and with sodium caseinates-stabilized emulsions a $\Gamma$ value ranging between 1.2 and $5.5 \mathrm{mg} \mathrm{m}^{-2}$ should be expected. In emulsions free of low molecular weight surfactants, the interpretation of $\Gamma$ values, which may be roughly deduced from the [Prot]: $A_{s p}$ ratio, should take into account the two opposing influences of the protein concentration. First, and as logically expected, by enhancing the probability of interfacial adsorption, any increase in the caseinate concentration increases $\Gamma$. Second, by enhancing the dispersion of droplets, the interfacial spreading of caseinates could also decrease the amount of adsorbed proteins per unit of area. In emulsions that contain a mixture of likely competitive surfactants, such as caseinates and monoglycerides, it seems that the influence of the caseinate concentration can be interpreted in terms of competition between i) monoglycerides and proteins to be adsorbed on the fat globule surface, and ii) fat and monoglycerides to bind proteins at high [GMS]. From figures 2B, 2D and 3 , it can be concluded that any reduction of the GMS:protein molecular ratio favours a better protein adsorption at the fat globule surface, and consequently an increase in $F_{\text {ads }}$ and $\Gamma$; more abundant and/or more surface active than proteins, monoglycerides probably settle at the interface quicker than proteins. The protein adsorption should then be evaluated in terms of the remaining free space at the serum-fat interface. In addition, it was previously observed that the average droplet size of milkfat globules increased with [GMS] at high [Prot] (Robin et al, 1992), which is not invalidated by electron micrographies $3 \mathrm{~A}, \mathrm{~B}$ (photo 1) and $4 \mathrm{~A}$ (photo 2). Indeed, in these emulsions where [GMS] and [Prot] were quite high ([Prot] $=1.5 \mathrm{wt} \%$ and $0.3 \leq[G M S] \leq 1.5 w t \%)$, fat globules were no longer spherical but partly melted due to a possible deficit in membrane material (photo $2,4 \mathrm{~B}$ ). This may be due to some kind of competition for protein binding between monoglycerides and fat. This competition could arise from the higher number of monoglyceride molecules per residue of caseinate and should be characterized by the formation of surface inactive weak complexes produced by the binding of hydrophobic areas of proteins and monoglycerides. At higher R, fat globules transform back to spheres with distinct and uniform membranes (photo 2,6Aand B). These two hypotheses have been schematically summarized in figure 4 where the influence of $R$ on the average fat globule diameter $\left(d_{v s}\right)$ and on the protein adsorption parameters $\left(F_{a d s}\right.$ and $\left.\Gamma\right)$ have been illustrated.

\section{CONCLUSION}

The studied process and composition variables affected in varying proportions, the parameters of protein surface adsorption $\left(F_{\text {ads }}\right.$ and $\Gamma$ ) in model dairy oil-in-water emulsions which both contained proteins (sodium caseinates) and a low molecular mass surfactant (monoglycerides). The respective influences of these process and composition variables on $F_{\text {ads }}$ and $\Gamma$ have been summarized in figure 5 . In order of importance, the sodium caseinate concentration, the monoglyceride concentration, the butter oil concentration, the emulsification pressure and finally the emulsification temperature had the greatest influence on the protein surface concentration parameters $\left(F_{a d s}\right.$ or $\left.\Gamma\right)$. 
The determination of the amount of adsorbed protein, by centrifugation straight after homogenization and by evaluation of the protein content, showed that sodium caseinates, as a group, seem much less easily adsorbed than GMS molecules when the GMS:protein molecular ratio $R$ is higher than 5 .

Finally and although they are preliminary results, the competitive adsorption between proteins and monoglycerides during emulsification appears to follow a rather simple mechanism (some kind of decreasing exponential function linking $F_{\text {ads }}$ or $\Gamma$ to $R$ ) for $R \geq 5$. This competitive adsorption mechanism underlies the concept, though not completely satisfying, of the 'remaining' free space at the interface.

\section{ACKNOWLEDGMENTS}

O Robin is indebted to Pr P Walstra (University of Wageningen, The Netherlands), Dr DG Dalgleish (University of Guelph, Canada) and Dr $S$ Gay (Université Laval, Canada) for providing helpful discussion and comments. O Robin also thanks Mrs V Blanchot (Centre de Recherche STELA, Université Laval) for initiating this work and producing preliminary results, and Mrs D Montpetit (Agriculture Canada, Saint-Hyacinthe, Canada) for preparing emulsion samples for microscopy analysis. The authors are indebted to $\operatorname{Pr}$ A Boudreau, $\operatorname{Dr} B$ Liang, and $\operatorname{Dr} Y$ Shi from the Département de Sciences et Technologie des Aliments (Université Laval), for providing butter oil and its physicochemical characteristics. Finally, the authors acknowledge the Conseil de la Recherche en Sciences Naturelles et Génie du Canada for their financial support.

\section{REFERENCES}

Allan-Wojtas P, Kalab M (1984) Milk gel structure. 14. Fixation of fat globules in whole milk yoghurt for electron microscsopy. Milchwissenschaft 39, 323-327

Arai T, Norde W (1990) The behavior of some model proteins at solid-liquid interfaces. 1. Adsorption from single proteins solutions. Colloids Surfaces 51, 1-15

Barry BW (1975) Viscoelastic properties of concentrated emulsions. Adv Colloid Interface Sci 5, 37-75

Blanchot V (1992) Influence des paramètres de formulation sur la charge protèique d'une émulsion laitière modèle. M Sc Thesis, Université Laval, Sainte-Foy, Canada

Boyd JV, Mitchell JR, Irons L, Mussellwhite PR, Sherman $P$ (1973) The mechanical properties of milk protein films spread at the air-water interface. J Colloid Interface Sci 45, 478-486

Britten M, Giroux HJ (1991) Emulsifying properties of whey protein and casein composite blends. J Dairy Sci 74, 3318-3225

Britten M, Giroux HJ (1993) Interfacial properties of milk protein-stabilized emulsions as influenced by protein concentration. I Agric Food Chem 41, 1187 1191

Brynda E, Houska M, Lednicky F (1986) Adsorption of human fibrinogen onto hydrophobic surfaces: the effect of concentration in solution. J Colloid Interface Sci 113, 164-171

Castle J, Dickinson E, Murray BS, Stainsby G (1987) Mixed protein films adsorbed at the oil-water interface. In: Proteins at Interfaces: Physicochemical and Biochemical Studies (JLBrash, TA Horbett, eds) ACS Symp Series 343, American Chemical Society, Washington, DC, USA, 118-134

Cheftel JC, Cuq JL, Lorient D (1985) Protéines alimentaires. Tec et Doc Lavoisier, Paris, France, 156-192

Closs B, Courthaudon JL, Lorient D (1990) Effect of chemical glycosylation on the surface properties of the soluble fraction of casein. J Food Sci 55,437 439; 461

Cohen Stuart MA, Fleer GJ, Scheutjens JMHM (1984) Displacement of polymers. 1. Theory. Segmental adsorption energy from polymer desorption in binary solvents. J Colloid Interface Sci 97, 515-525

Courthaudon JL, Dickinson E, Christie WW (1991a) Competitive adsorption of lecithin and $\beta$-casein in oil in water emulsions. J Agric Food Chem 39, 1365 1368

Courthaudon JL, Dickinson E, Dalgleish DG (1991b) Competitive adsorption of $\beta$-casein and nonionic surfactants in oil-in-water emulsions. J Colloid Interface Sci 145, 390-395

Courthaudon JL, Dickinson E, Matsumura $Y$ (1991c) Competitive adsorption of $\beta$-lactoglobulin + Tween 20 at the oil-water interface. Colloids Surfaces 56 , 293-300

Dalgleish DG (1994) Structures and properties of emulsions containing milk proteins. In: Proc Food Macromolecules and Colloids, 23-25 March 1994, Dijon, France

Dalgleish DG, Robson EW (1985) Centrifugal fractionation of homogenized milks. J Dairy Res 52, 539546

Dalgleish DG, Euston, SE, Hunt, JA, Dickinson E (1991) Competitive adsorption of $\beta$-lactoglobulin in mixed protein emulsions. In: Food Polymers, Gels and Colloids (E Dickinson, ed) Royal Society of Chemistry, Cambridge, UK, 485-489

Darling DF, Butcher DW (1978) Milk fat globule membrane in homogenized cream. J Dairy Res 45,197 . 208 
Das KP, Kinsella JE (1990) Effect of heat denaturation on the adsorption of $\beta$-lactoglobulin at the oil/water interface and on coalescence stability of emulsions. $J$ Colloid Interface Sci 139, 551-560

de Feijter JA, Benjamins J, Tamboer M (1987) Adsorption displacement of proteins by surfactants in oil-in water emulsions. Colloids Surfaces 27, 243-266

Dickinson E (1992) An Introduction to Food Colloids. Oxford Science Publications, London, UK, 154-155

Dickinson E, Woskett CM (1989) Competitive adsorption between proteins and small surfactants in food emulsions. In: Food Colloids (RD Bee, P Richmond, $J$ Mingins, eds) Royal Society of Chemistry, London, UK, 74-96

Dickinson E, Matsumura $Y$ (1991) Time-dependent polymerisation of $\beta$-lactoglobulin through disulphide bonds at the oil-water interface in emulsions, Int $J$ Biol Macromol 13, 26-30

Dickinson E, Gelin JL (1992) Influence of emulsifier on competitive adsorption of $\alpha_{5}$-casein $+\beta$-lactoglobulin in oil-in-water emulsions. Colloids Surfaces 63 , 329-335

Dickinson E, Tanai S (1992a) Protein displacement from the emulsion droplet surface by oil-soluble and water-soluble surfactants. J Agric Food Chem 40 , 179-183

Dickinson E, Tanai S (1992b) Temperature dependence of the competitive displacement of protein from the emulsion droplet surface by surfactants. Food $\mathrm{Hy}$ drocolloids 6, 163-171

Dickinson E, Mauffret A, Rolfe SE, Woskett CM (1989a) Adsorption at interfaces in dairy systems. J Soc Dairy Technol 42, 18-22

Dickinson E, Rolfe SE, Dalgleish DG (1989b) Competitive adsorption in oil-in-water emulsions containing $\alpha$-lactalbumin and $\beta$-lactoglobulin. Food Hydrocolloids 3, 193-203

Dickinson E, Euston SR, Woskett CM (1990) Competitive adsorption of food macromolecules and surfactants at the oil-water interface. Prog Colloid Polym Sci $82,65-75$

Dickinson E, Owusu AK, Tan S, Williams A (1993) Oilsoluble surfactants have little effect on competitive adsorption of $\alpha$-lactalbumin and $\beta$-lactoglobulin in emulsions. J Food Sci 58, 295-298

Doxastakis G, Sherman P (1986) The interaction of sodium caseinate with monoglyceride and diglyceride at the oil-water interface and its effect on interfacial rheological properties. Colloid Polym Sci 264, 254259

Fisher LE, Parker NS (1988) Effect of surfactants on the interaction between emulsion droplets. In: $A d$ vances in Food Emulsions and Foams (E Dickinson, ed) Elsevier Applied Science, London, UK, 45-90

Friberg S, Jansson PO, Cederberg E (1976) Surfactant association structure and emulsion stability. $J \mathrm{Col}$ loid Interface Sci 55, 614-623

Gaonkar AG, Borwankar RP (1991) Competitive adsorption of monoglycerides and lecithin at the vegetable oil-water interface. Colloids Surfaces 59, 331343
Graham DE, Phillips MC (1979) Proteins at liquid interfaces. 1. Kinetics of adsorption and surface denaturation. J Colloid Interface Sci 76, 403-414

Graham DE, Phillips MC (1980) Proteins at liquid interfaces. 4. Dilatational properties. J Colloid Interface Sci 76, 227-239

Heertje I, Nederlof J, Hendrickx HACM, LucassenReynders EH (1990) The observation of the displacement of emulsifiers by confocal scanning laser microscopy. Food Struct 9, 305-316

Hunt JA, Dalgleish DG (1994) Adsorption behaviour of whey protein isolate and caseinate in soya oil-inwater emulsions. Food Hydrocolloids 8, 175-187

International Dairy Federation (1986) Milk: determination of nitogen content (Kjeldahl method). Provisional Int Standard 20A

Krog NJ (1990) Food emulsifiers and their chemical and physical properties. In: Food Emulsions, 2nd edn (K Larsson, SE Friberg, eds) Marcel Dekker Inc, New York, USA, 127-180

Krog NJ (1991) Thermodynamics of intertacial films in food emulsions. In: Microemulsions and Emulsions in Foods (M El-Nokaly, D Cornell, eds) ACS Symp Series 448, American Chemical Society, Washington, DC, USA, 138-145

Leman J, Kinsella JE (1989) Surface activity film formation and emulsifying properties of milk proteins. CRC Crit Rev Food Sci Nutr 28, 115-136

Lorient D, Closs D, Courthaudon JL (1991) Connaissances nouvelles sur les propriétés fonctionnelles des protéines du lait et de ses dérivés. Lait 71,141 171

Mulder H, Walstra P (1974) The milk fat globule: emulsion scierice as applied to milk products and comparable foods. Commonwealth Agricultural Bureaux, Farnham Royal, Bucks, UK, 18; 175-178

Nakai S (1983) Structure-relationships of food proteins with an emphasis on the importance of protein hydrophobicity. J Agric Food Chem 31, 676-683

Ogden LV, Walstra P, Morris HA (1976) Homogenization-induced clustering of fat globule in cream and model systems. J Dairy Sci 59, 1727-1737

Oortwijn H, Walstra P (1979) The membranes of recombined fat globules. 2. Composition. Neth Milk Dairy J33, 134-154

Pearce KN, Kinsella JE (1978) Emulsitying properties of proteins: evaluation of a turbidimetric technique. $J$ Agric Food Chem 26, 716-723

Rémillard N, Robin O, Martel R, Pequin P (1993) Influence of homogenization efficiency on milk fat content determination by infrared analysis. Int Dairy $\mathrm{J} 3$, 197-208

Reynolds ES (1963) The use of lead citrate at high pH as an electron-opaque stain in electron microscopy. J Cell Biol 17, 208-212

Robin O, Paquin P (1991) Evaluation of the particle size of fat globules in a milk model emulsion by photon correlation spectroscopy. J Dairy Sci 74, 2440-2447

Robin O, Blanchot V, Vuillemard JC, Paquin P (1992) Microfluidization of dairy model emulsions. 1. Preparation of emulsions and influence of processing 
and formulation on the size distribution of milk fat globules. Lait 72, 511-531

Robin O, Rémillard N, Paquin, P (1993) Influence of major process and formulation parameters on microfluidized fat globule size distribution and example of a practical consequence. Colloids Surfaces A: Phys Eng Aspects 80, 211-222

SAS Institute Inc (1990) SAS/STAT User's Guide: Statistics. Version 6.06, 4th edn, vol 2, Cary, NC, USA, 891-996; 1351-1456

Tomas A, Paquet D, Courthaudon JL, Lorient D (1994a) Effect of fat and protein contents on droplet size and surface protein coverage in dairy emulsions. J Dairy Sci $77,413-417$

Tomas A, Paquet D, Courthaudon JL, Lorient D (1994b) Effect of surfactants on some physico-chemical properties of dairy oil-in-water emulsions. Food Hydrocolloids 8, 543-553

Tornberg E (1978) Functional characterization of protein stabilized emulsions: emulsifying behaviour of proteins in a valve homogeniser. J Sci Food Agric 29, 867-879

Walstra P (1975) Effect of homogenization on the fat globule size distribution in milk. Neth Milk Dairy $J$ 29, 279-294
Walstra P (1983) Emulsion formation. In: Encyclopedia of Emulsion Technology. 1. Basic Theory (P Becher, ed) Marcel Dekker Inc, New York, USA, 57-127

Walstra P (1987) Overview of emulsion and foam stability. In: Food emulsions and foams (E Dickinson, ed) Royal Society of Chemistry, London, UK, 242257

Walstra P, Oortwijn $\mathrm{H}$ (1982) The membranes of recombined fat globules. 3. Mode of formation. Neth Milk Dairy J 36, 103-113

Walstra P, Jenness R, Badings HT (1984) Dairy Chemistry and Physics. John Wiley \& Sons, New York, USA, 212-215

Wüstneck R, Müller HJ (1986) Characterization of gelatin-surfactant interaction by thickness measurements of foam films. Colloid Polym Sci 264, 97-102

Wüstneck R, Hermel H, Kretzschmar G (1984) Beeinflussung der oberflächeneigenschaften des systems gelatine + tensid durch die art der gelatine. Colloid Polym Sci 262, 827-832

Zsom RLJ (1986) Dependence of preferential bovine serum albumin oligomer adsorption on the surface properties of monodisperse polystyrene lattices. $\checkmark$ Colloid Interface Sci 111, 434-445 